\title{
The Didactic Potential of University Electronic Information and Educational Environment in the Context of a Pandemic
}

\section{El potencial didáctico de la información electrónica universitaria y el entorno educativo en el contexto de una pandemia}

\author{
Natalia Anatolyevna Kostikova* \\ Vyborg Branch of the Herzen State Pedagogical University of Russia, Vyborg, Russia \\ ORCID: https://orcid.org/0000-0001-5438-7317
}

\section{Zotik Semenovich Kuzin}

Admiral Makarov State University of Maritime and Inland Shipping, Saint Petersburg, Russia ORCID: https://orcid.org/0000-0003-3204-8714

\section{Irina Borisovna Gotskaya}

Herzen State Pedagogical University of Russia, Saint Petersburg, Russia National Research University of Information Technologies, Mechanics and Optics, Saint Petersburg, Russia ORCID: https://orcid.org/0000-0003-3074-8936

\section{Elena Yurevna Avksentieva}

Herzen State Pedagogical University of Russia, Saint Petersburg, Russia

ORCID: https://orcid.org/0000-0001-5000-4868

Mikhail Semenovich Prokopiev (D) M.K. Ammosov North-Eastern Federal University, Yakutsk, Russia ORCID: https://orcid.org/0000-0002-7565-8902

*Correspondence

Email: nataliakostikova@inbox.ru
Cite as:

Kostikova, N. A., Kuzin, Z. S., Gotskaya, I. B., Avksentieva, E. Y., \& Prokopiev, M. S. (2020). The Didactic Potential of University Electronic Information and Educational Environment in the Context of a Pandemic. Propósitos y Representaciones, 8 (SPE3), e707. Doi: http://dx.doi.org/10.20511/pyr2020.v8nSPE2.707 


\section{Summary}

The article outlines the possibilities of using a University Electronic Information-Educational Environment (EIEE) that facilitates the University educational process in the context of a pandemic considering the variety of applicable e-learning tools and difficulties encountered by teachers and students in organizing and implementing distance learning within this period. The major objective of the article is revealing the didactic potential and technologies for providing remote access to University educational resources for arranging the educational process. Study results. The study identified E-resources and electronic environment activities that found to be the most popular between educational process participants in the period of forced transition to distance learning. Besides, the authors list the main difficulties in distance learning arrangement and suggested ways in their overcoming aided by EIEE didactic possibilities and potential. The principal research methods are questionnaire survey, expert assessment method and statistical processing of quantitative research results. The practical implications of the study comprise recommendations development for distance learning arrangement providing for modifying various components of students' training system in higher education institutions, which is especially important not only in the context of a pandemic, but also under standard academic situations. The paper sets the direction of further research in upgrading the education system. The materials of the article can be helpful to teachers of higher educational institutions, further education establishments, to heads of educational institutions and school teachers in resolving the issues of organizing educational activities in the context of a pandemic for successful fulfillment of the basic educational programs.

Keywords: Distance Education; Electronic Information; Educational Environment; ELearning; Pandemic.

\section{Resumen}

En el artículo se esbozan las posibilidades de utilizar un Entorno Educativo de Información Electrónica Universitaria (EIEE) que facilite el proceso educativo de la Universidad en el contexto de una pandemia, teniendo en cuenta la variedad de instrumentos de aprendizaje electrónico aplicables y las dificultades con que tropiezan los profesores y los estudiantes para organizar y aplicar la enseñanza a distancia en este período. El principal objetivo del artículo es revelar el potencial didáctico y las tecnologías para proporcionar acceso a distancia a los recursos educativos de la Universidad para organizar el proceso educativo. Resultados del estudio. En el estudio se identificaron los recursos electrónicos y las actividades del entorno electrónico que resultaron ser las más populares entre los participantes en el proceso educativo en el período de transición forzosa a la enseñanza a distancia. Además, los autores enumeran las principales dificultades en la organización de la enseñanza a distancia y sugieren formas de superarlas con la ayuda de las posibilidades y el potencial didáctico del EIEE. Los principales métodos de investigación son la encuesta por cuestionario, el método de evaluación por expertos y el procesamiento estadístico de los resultados de la investigación cuantitativa. Las consecuencias prácticas del estudio comprenden la elaboración de recomendaciones para la organización de la enseñanza a distancia que prevean la modificación de diversos componentes del sistema de formación de los estudiantes en las instituciones de enseñanza superior, lo que es especialmente importante no sólo en el contexto de una pandemia, sino también en situaciones académicas normales. El documento establece la dirección de las investigaciones futuras para mejorar el sistema educativo. Los materiales del artículo pueden ser útiles para los profesores de las instituciones de educación superior, los establecimientos de educación superior, los directores de las instituciones educativas y los profesores de las escuelas para resolver los problemas de organización de las actividades educativas en el contexto de una pandemia para el cumplimiento exitoso de los programas educativos básicos.

Palabra clave: Educación a Distancia; Información Electrónica; Entorno Educativo; E- 
Learning; Pandemia.

\section{Introduction}

Since September 2013, the new law of the Russian Federation "On education" has come into effect. It is focused on using e-learning and distance learning technologies. It opens new prospects for universities in providing educational services, and thereby sets new challenges. Moreover, a number of regulatory documents, such as "Strategy of the Information Society Development in the Russian Federation for 2017-2030" (2016), the Program "Digital economy of the Russian Federation" (Government of the Russian Federation, 2017) specify the necessity of expanding and integrating electronic resources in various areas, including education, and increasing the number of electronic resources' users. It is not the degree of distance learning "remoteness" that seems to be relevant now, but instead using electronic environment as one of the most important technologies of conventional professional education within the Electronic Information-Educational Environment (EIEE) of an educational institution. University Electronic Educational Environment (EEE) formation and integration into the unified information educational space of the country and the world contribute to improving the quality of traditional full-time and distance education. Quality enhancement is catered by improving teaching aids and speed of access to them, enrichment of teaching staff skills and skills of other staff supporting the educational process, better organization of educational process, implementing mixed (combined) teaching patterns matched by distance learning, a comprehensive solution of issues in development, implementation and support of higher professional education programs.

It is quite natural that modern distance learning technologies and e-learning are gaining popularity in educational process of various target groups. Thus, the main EIEE goal at M. K. Ammosov North-Eastern Federal University named after (NEFU) and A. I. Herzen Russian State Pedagogical University (RSPU) in the context of a pandemic is providing remote access (in authorized mode, oriented at different users) to University educational resources and ensuring use of remote access for educational purposes by e-learning tools.

EIEE is a system of tools and resources facilitating conditions for educational activity based on information and communication technologies. EIEE as a tool for extending access to higher education has aroused great students' interest. EIEE software platform incorporates a set of University-developed software systems: a web portal, Moodle distance learning system (n.d.) and the University information system. Using Moodle system (n.d.) enables creating electronic teaching materials, performing testing and managing teaching and its support in EEE.

Teachers of University faculties develop varied electronic educational resources (EOR): electronic educational and methodological complexes in high demand due to abundance in University's curricula of disciplines requiring a strong laboratory base. EOR are made available in the electronic library system on the University portal, which contains more than 5 thousand resources. When evaluating the activities of departments and faculties, one of the rating indicators is the "Number of EOR on the University portal" (NEFU and RSPU). The systematic training of teachers to enable teaching in the distance learning mode via EIEE is provided by a set of activities enabling teachers with any initial level of IT competence to master using the software systems comprised in EIEE.

It should be noted that in many Russian educational institutions, e-learning occupies so far the rightful place in the educational process. E-learning is run using the automated distance learning systems (for example, "Electronic University" (n.d.), Moodle (n.d.), "Prometheus" (1999-2020), "Docent" (UNIAR, 2002-2015), WebTutor (2018), etc.) that enable teachers to arrange access to information and educational support programs, to keep indirect communications using information technologies for continuous Internet support of educational process (Alrubaie et al., 2020; Alasmri et al., 2019). 


\section{Literature Review}

Much research on using e-learning in higher education and its various aspects has been done by foreign researchers. Holbeck and Hartman (2018) in their research note effective strategies for maximizing student satisfaction from using online technologies to extend their cognitive and social presence and presence of a teacher to obtain empirical data about consequences of using these tools and strategies, as well as other ones that have not been discussed here. The structure of a flexible virtual program for distance education at Columbia State University is presented in the paper by Vargas and Kalman (2018). The article describes some teaching patterns and analyzes students' participation in the online forum used to work out learning activities within an online course conducted on the Moodle platform (n.d.). Online interaction of two students' groups during practice classes is discussed (Vargas \& Kalman, 2018). Using business analysis and analytics tools to examine the impact of interactivity and interaction on performance of distance learning students at initial level in virtual learning environments is discussed by Ichihara and Nizam (2018). The study was conducted using data of a Brazilian private distance learning University that uses a virtual learning environment (Ichihara \& Nizam, 2018). Hossain et al. (2018) emphasize that scientific standards of NGSS generation and other national structures require much more sophisticated approach to STEM education. They are centered around complex experiment integration, data collecting and their analysis, simulation and databased argumentation, i.e. students can behave like real scientists. Ways of implementing such integrated approaches in scalable ways remains an unsolved problem for both full-time and distance education.

In particular, the author of the paper by Pathak (2016) examines development of online educational models that inspire changes in educational process at traditional universities. It requires studying the methodology of teaching specific subjects online. The pedagogical problems of teaching research methods and mathematical statistics in e-learning environment are examined in the article by Rock et al. (2016). The authors provide some practical examples of online work with students. The focus in a number of studies was on various aspects of teachers' training for their professional activity when blended and all-pervading learning are more and more common, and teachers invariably need innovative electronic information educational environments (Schulz et al., 2014) affected by strengthening economic and market factors in motivation for educational activity (Clark \& Mayer, 2016) and being aware of evolution of interaction patterns between educators and learners (Mohammad et al., 2013).

The theoretical basis of the research rests on papers by Russian authors on using distance and electronic education forms (Vlasova \& Gosudarev, 2015). We also rely on foreign publications by researchers of scientific schools of E. A. Barakhsanova (NEFU) and E. Z. Vlasova (RSPU) in development and spreading of modular training programs for teachers related to organization and implementation of network education in the region. These studies deal with problems of distance learning, provide theoretical foundations for research in distance education and e-learning, evaluate the efficiency of adaptive teaching in e-learning systems based on structuring teaching aids stored in databases (Barakhsanova et al., 2018a, 2018b; Vlasova et al., 2018, 2019a).

\section{Materials and Methods}

The study discussed in this paper is based on results of a long-term experiment participated by RSPU first-year students (Bachelors of faculties of Sciences and Humanities) majoring in "Pedagogical Education", as well as RSPU and NEFU Master's students majoring in "Pedagogical Education" (Master's programs "Technologies and management of e-learning", "Corporate e-learning”). More than 5,000 Bachelor's and 48 Master's students were engaged in the experiment. 
After completion of studying the discipline "Information technology", Bachelor's students were asked to answer the question: "Do you find studying the discipline useful in terms of its content, form and teaching methods?" For all years of the experiment, not a single negative answer was obtained. Moreover, all respondents highlighted the efficiency of training in the proposed e-learning environment (IT Flow, 2011-2020) developed by teachers of RSPU Department of Computer Technologies and E-Learning. This EIEE is focused on versatile use of e-learning technologies applied to tasks adapted to teachers' future professional activity.

Each year, students who completed studying the discipline were split into two groups (Group 1-Science students, Group 2 - Humanities students). Each group was asked to answer the question: "In view of your professional development, do you believe it is purposeful to continue studying e-learning technologies related to tasks of your professional activity"? At the level of significance $\alpha=0.02(\gamma=0.98)$, the hypothesis of equality of an attribute share was verified, namely, the hypothesis that both Science and Humanities students consider it purposeful to continue studying e-learning technologies related to tasks of their professional activity.

The study was also participated by Master's students from two universities who studied e-learning purposefully. They were trained with an active use of e-learning technologies that significantly changed educational activities of both students and teachers. RSPU and NEFU Master's students were asked to answer the question: "Which of the listed properties of a new educational activity affect the efficiency of modern teacher's professional training? Put them in the order of importance." We tested the hypothesis that the correlation between two ordered groups of properties in RSPU and NEFU samples was significantly different from zero (i.e., opinions of students from two universities on the examined issue are similar). Results' processing was done using Spearman's rank correlation method.

Resulting from curricula analysis, monitoring of educational process in a number of pedagogical universities in Russia, and discussions with other pedagogical university teachers, the general conclusion was made that information technologies learning by students is reduced to studying practices of working with these technologies, often illustrated by tasks being far from education. Moreover, teachers of the higher pedagogical school do not use e-learning technologies when delivering classes.

The baseline methodological prerequisites of the study included: 1) development of a new content for training pedagogical university students in information technologies with a focus on its practical application to solve professional problems of education and e-learning; 2) modifying the educational process nature by engaging students in active practices, including elearning technologies application; 3) implementation of students' training in EIEE adapted to their future professional activities; 4) development by students of their own EIEE using common information technologies. The study participants set the goal not only to teach students how to use properly the offered information technologies, but also to motivate students to actively use them as tools for learning, self-learning, and for practicing new adaptive educational activities in EIEE.

In the face of the pandemic that caused a compelled shifting at all education levels to distance education, a whole complex of problems arose related to educational process organization and students' preparation for future professional activities. If before the pandemic, educational process participants had an opportunity and freedom to choose an option, a method, and route of education, distance learning turned out to be the only possible option. In this context, it was absolutely necessary to outline the problems of distance learning arrangement and EIEE didactic potential.

The study was performed from March to June 2020 by a team of authors being representatives of two Russian universities (NEFU, the Republic of Sakha (Yakutia) and RSPU, 
Saint Petersburg), and RSPU Vyborg branch. It was intended for a more profound understanding of problems and challenges of effective educational specialists' training and their adaptation to working in EIEE, for identifying and developing the general, specific and relevant educational technologies adapted to regional characteristics and possible risks. A few experiments were conducted to explore the demand for various tools for organizing e-learning and to reveal difficulties experienced by both students and teachers in distance learning organizing and implementing. Spearman's rank correlation method was used to process the results. In addition, students and teachers were asked to identify the types of activities that presented the greatest difficulties in distance learning arrangement.

\section{Results}

At Stage 1 of the experimental study, teachers and students were asked to arrange 10 tools for elearning during the pandemic in order of their being essential. The answers are presented in Table 1.

Table 1.

The Answers

\begin{tabular}{ccc}
\hline Teachers' Score $x_{i}$ & Tool & Students' Score $y_{i}$ \\
\hline 1 & Moodle distance learning system & 2 \\
2 & Video conferencing systems & 1 \\
3 & Russian online courses & 9 \\
10 & Foreign online courses & 10 \\
8 & Messengers & 7 \\
6 & Social networks & 5 \\
4 & Educational videos & 3 \\
9 & Google class & 8 \\
7 & Podcasts & 6 \\
5 & Interactive programs in subjects & 4 \\
\hline
\end{tabular}

It was examined what is the rank correlation between two rows of scores. Therefore, a conclusion can be made about the coincidence degree of teachers' and students' opinions. After finding the rank difference:

$$
d_{i}=x_{i}-y_{i}
$$

Spearman's coefficient was calculated:

$$
r_{s}=1-\frac{6 \sum d_{i}^{2}}{n\left(n^{2}-1\right)}
$$


Its value was 0.7333 .

It was checked for a positive correlation between teachers' and students' opinions. In this view, Student's t-statistics was calculated:

$$
t=\left|r_{s}\right| \sqrt{\frac{n-2}{1-r_{s}^{2}}}
$$

A null hypothesis is formulated that the correlation coefficient is not statistically significant. An alternative hypothesis says there is a positive correlation.

At significance level $\alpha=0.05$ :

$$
\begin{aligned}
& t_{k r}=1.86 \\
& t_{\text {calc }}=3.0505
\end{aligned}
$$

Thus, $3.05>1.86$. As we can see, the relationship between teachers' and students' opinions is statistically significant at $5 \%$ significance level.

At Stage 2 of the experiment, we investigated the difficulties experienced by teachers and students in distance learning organizing and implementing. The subjects were asked to mark (using a 10-point scale) which difficulties were most/ least significant from their point of view. The results are shown in Table 2 .

Table 2.

The Results

\begin{tabular}{ccc}
\hline Teachers & Difficulties & Students \\
$x_{i}$ & $y_{i}$ \\
\hline 1 & Instability of Moodle distance learning system \\
functioning & 1 \\
8 & Internet quality & 10 \\
9 & Lack of Moodle operating skills & 7 \\
2 & Unavailability of the device needed & 8 \\
10 & A lot of tasks to do & 9 \\
6 & You need to spend a lot of time with the device & 3 \\
7 & Occurrence of health problems & 7 \\
3 & Insufficient communication with a teacher or with a & 2
\end{tabular}


$4 \quad$ Insufficient communication with colleagues

The rank correlation between teachers' and students' answers was calculated and analyzed. The Spearman coefficient's value was equal to $r_{s}=0.6667$.

Calculation of Student t-statistics showed $t_{\text {calc }}=2.53$. At the significance level $\alpha=0.05 t_{c r}=1.86$. We obtained $t_{c a l c}>t_{c r}$. Therefore, we can conclude that at $5 \%$ significance level, opinions of teachers and students coincided. They are experiencing nearly the same difficulties.

To reveal the activity types that were the students found to be the most difficult during distance learning, a questionnaire survey was conducted. The analysis of survey results showed that these activities were as follows: performing practical tasks in disciplines, viewing video lectures, interacting with teachers and students, independent work, project activities, performing tests, testing, co-editing materials (wiki), information searching and processing, and content filling.

For teachers in varying degrees, the most complex activities in distance learning platform (Moodle (n.d.)) were: preparation and placement of video lectures, placement of textual information (materials) for classes, preparation and placement of tasks for seminars, placement of presentations for lectures and practical classes, organization of communication with students, testing materials development, organizing control, organizing feedback from students, selecting of additional electronic resources and services, and checking over completed papers.

\section{Discussion}

Distance education arrangement during the pandemic revealed a number of serious problems and contradictions. Their resolving will significantly improve the quality of educational process and of students' preparation in different profiles for their future professional activities. Besides, it will also broaden the opportunities and prospects of using EIEE resources.

The results thus obtained show that under standard teaching conditions, University teachers, as a rule, did not manifest high activity in using EIEE resources. Despite the fact that EIEE provides a wide range of didactic options, many university teachers and students who participated in the study stipulated a rather long list of activities to have caused difficulties during forced transition to distance learning.

For dealing with the complexities above, the following remedy actions are required:

1) Considering EIEE features and structure, bring them to attention of both teachers and students, along with EIEE didactic opportunities and potential for solving professional tasks;

2) Development of a new content for educating pedagogical university students in various subjects, taking into account the necessity to implement e-learning technologies and distance education technologies;

3) Updating the educational content as to information technologies with a focus on their practical application to solve professional problems of education and e-learning;

4) Changing the educational process nature by engaging students in active practices during the learning process, including using e-learning technologies;

5) Implementing students' training in an electronic information and educational environment adapted to their future professional activities; 
6) Development of students' personal electronic educational environment using information technologies practiced by everyone;

7) Arranging training and upgrading qualifications of higher education teachers in areas of EIEE components design, effective integration of EIEE resources into the educational process, selecting technologies for learning and interaction.

The organizational aspect of EIEE development involves identifying, first, the essence of the environment being examined, second, its component structure, third, the content of these components, fourth, their interaction, fifth, control over its sections formation of and some other items.

In Federal State Educational Standard of Higher Professional Education (n.d.) for all specialties and areas of education reads that within the whole period of training, each student shall be provided with an individual unlimited access to one or more e-library systems (digital libraries) and to EIEE of an institution. The regulatory documents do not specify types of EIEE components, but they clearly stipulate what EIEE shall provide:

- Access to curricula, working programs of disciplines (modules), practices, to publications of electronic library systems and electronic educational resources listed in working programs;

- Documenting the educational process in progress, midterm assessment results and results of mastering the basic educational program;

- Delivery of all-type classes and conducting learning results assessment that shall be implemented using e-learning and distance learning technologies;

- Compilation of student's electronic portfolio, including keeping student's papers and their reviews and evaluations by any educational process subjects;

- Interaction between participants of educational process, including synchronous and (or) asynchronous interaction via the Internet.

The study confirmed that more efficient using of EIEE didactic potential in higher education institutions requires making changes to content and technology of students' training; providing conditions for intensifying the activity of students due to engaging them in various activities in EIEE framework; selecting appropriate modes, strategies and tactics of communicative interaction. Special attention should be paid to teachers' training and upgrading their qualifications in educational process organization using EIEE resources and potential and in EIEE technical and technological component.

\section{Conclusion}

E-learning implementation in Russia and abroad is related to informatization of educational process, realization of continuous, open education laying the basis of information society It enables meeting the growing demand for education services, integrating into the international scientific community, becoming subjects of intercultural communication and international cultural exchange (Kostikova, 2019; Vlasova et al., 2019b).

According to expert data, about $70 \%$ of foreign students choose distance education, but the number of such students in Russia is low so far. Introduction of e-learning in the Russian educational system is relevant. An extensive territory and a significant number of people living in small towns and rural areas with insufficient level of communication facilities complicate exercising citizens' constitutional right to education.

The worldwide popularity of distance learning is justified, first of all, not only by the coronavirus pandemic broke out worldwide, but by the fact that it provides accessibility the student needs, regardless of geographical location, age, and education level. Distance education 
pattern guarantees freedom to select a teacher from any educational organization that puts distance learning at the forefront.

It should be emphasized that creating conditions for running EIEE includes providing electronic information resources, electronic educational resources, a set of information technologies, telecommunications technologies, and relevant technological equipment to ensure mastering educational programs by students in full, irrespective of their location.

\section{References}

Alasmri, M., Onn, W. C., \& Hin, H. S. (2019). Social networking framework for learning motivation. Journal of Southwest Jiaotong University, 54(6). doi:10.35741/issn.02582724.54.6.47

Alrubaie, S. A., Alrubaie, M. A., \& Hassoon, I. M. (2020). The role of activating electronic training in increasing efficiency of training process. Journal of Southwest Jiaotong University, 55(1). doi:10.35741/issn.0258-2724.55.1.18

Barakhsanova, E. A., Golikov, A. I., Sorochinsky, M., Lukina, T., Ilina, E., \& Nikitina, E. V. (2018a). Implementation of the master program "corporate e-learning" in the online interaction of Russian universities. Espacios, 39(20), 36.

Barakhsanova, E. A., Varlamova, V. A., Vlasova, E. Z., Nikitina, E. V., Prokopyev, M. S., 7 Myreeva, A. N. (2018b). Vocational training of school teachers in Yakutia's universities through the principle of regionalization (case study of the methodology of teaching natural science to prospective teachers). Espacios, 39(20), 35.

Clark, R. C., \& Mayer, R. E. (2016). E-learning and the science of instruction: Proven guidelines for consumers and designers of multimedia learning. John Wiley \& Sons.

Electronic University. (n.d.). [https://online.pspu.ru/] [Accessed on 17 April, 2020].

Federal State Educational Standard of Higher Professional Education. (n.d.). [http://fgosvo.ru/fgosvpo/7/6/1] [Accessed on 17 April, 2020].

Government of the Russian Federation. (2017). The program "Digital Economy of the Russian Federation". [http://government.ru/projects/selection/743/28653/] [Accessed on 11 April, 2019].

Holbeck, R., \& Hartman, J. (2018). Efficient strategies for maximizing online student satisfaction: Applying technologies to increase cognitive presence, social presence, and teaching presence. Journal of Educators Online, 15(3). doi:10.9743/jeo.2018.15.3.6

Hossain, Z., Bumbacher, E., Brauneis, A., Diaz, M., Saltarelli, A., Blikstein, P., \& RiedelKruse, I. H. (2018). Design guidelines and empirical case study for scaling authentic inquiry-based science learning via open online courses and interactive biology cloud labs. International Journal of Artificial Intelligence in Education, 28(4), 478-507.

Ichihara, A., \& Nizam, O. (2018). The use of business intelligence tools to analyze the influence of interactivity and interaction factors on the assessment of distance students' performance in virtual learning environments. International Journal of Learning, Teaching and Educational Research, 17(9), 91-101.

IT Flow. (2011-2020). [https://inftech.spb.ru] [Accessed on 11 April, 2019].

Kostikova, N. A. (2019). Practical aspects of training future teachers to organize communication activities in the electronic educational environment. Educational Bulletin "Consciousness", 7(21), 13-18.

Law of the Russian Federation "On education". (2013). [https://nsportal.ru/zakon-obobrazovanii-2013-g] [Accessed on 15 April, 2020].

Mohammad, N. M., Sara, F., Zahra, T., \& Mojtaba, H. (2013). The study of the teacher's role and student interaction in e-learning process. Proceedings of the 4th International Conference on e-Learning and e-Teaching.

Moodle. (n.d.). [https://moodle.org/] [Accessed on 15 April, 2020].

Pathak, B. K. (2016). Emerging online educational models and the transformation of traditional universities. Electronic Markets, 26, 315-321.

Prometheus. (1999-2020). [https://iroio.prometeus.ru/portal/] [Accessed on 15 April, 2020]. 
Rock, A. J., Coventry, W. L., Morgan, M. I., \& Loi, N. M. (2016). Teaching research methods and statistics in eLearning environments: Pedagogy, practical examples, and possible futures. Frontiers in Psychology, 7, 339.

Schulz, R., Isabwe, G. M., \& Reichert, F. (2014). Supporting teachers' needs within and through E-learning systems. In Proceedings of the International Conference on Web and Open Access to Learning. Piscataway, NJ: Institute of Electrical and Electronics Engineers. doi:10.1109/ICWOAL.2014.7009228

Strategy of the Information Society Development in the Russian Federation for 2017-2030. (2016). [https://www.prlib.ru/en/node/675250] [Accessed on 10 June, 2020].

UNIAR. (2002-2015). Docent. [https://uniar.ru/docent.php] [Accessed on 10 June, 2020].

Vargas, R. M., \& Kalman, J. (2018). The construction of flexibility in a virtual program at a public Colombian distance education university. Revista De Educacion a Distancia, 58. doi: $10.6018 / \mathrm{red} / 58 / 8$

Vlasova, E. Z., Avksentieva, E. Y., Goncharova, S. V., \& Aksyutin, P. A. (2019a). Artificial intelligence - The space for the new possibilities to train teachers. Espacios, 40(9), 17.

Vlasova, E. Z., Goncharova, S., Aksyutin, P., Barakhsanova, E. A., Prokopyev, M. S., \& Kuzin, Z. (2018). Effective adaptive training of students in Russian pedagogical universities to use e-learning technologies. Espacios, 39(23), 10.

Vlasova, E. Z., Goncharova, S. V., \& Lukyanova, V. A. (2019b). Using the EdX platform for organizing corporate training. Modern Education: Traditions and Innovations, 1, 23-25.

Vlasova, E. Z., \& Gosudarev, I. B. (2015). E-learning in engineers' training. Proceedings of the Baltic State Academy of Fishing Fleet: Psychological and Pedagogical Sciences, 2(32), 32-39.

WebTutor. (2018). [https://www.webtutor.ru/] [Accessed on 10 June, 2020]. 